\title{
Conflitualidade e violência reflexões sobre a anomia na contemporaneidade
}

\author{
SÉRGIO ADORNO
}

\begin{abstract}
RESUMO: A partir de uma análise crítica de ensaio de Ralph Dahrendorf, Law and Order (1985), sobre a erosão da lei e da ordem na sociedade contemporânea, procura-se desconstruir os argumentos contidos no ensaio sugerindo as mudanças que incidem sobre o modo de assujeitamento dos indivíduos. Mais do que liberação dos indivíduos dos liames e controles sociais, para além de um problema de "ligaduras", o que parece estar no centro das radicais transformações da ordem neste final do século é o modo como os indivíduos governam a si e aos outros (Foucault, 1984). Para sustentar esta hipótese, toma-se como referência para a análise um caso determinado: a colonização da criminalidade urbana pelo crime organizado, em particular por uma das modalidades mais emblemáticas de produção da violência no mundo contemporâneo - o narcotráfico.
\end{abstract}

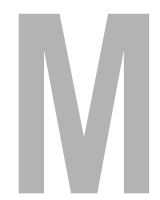

eu ponto de partida é o livro do sociólogo alemão Ralph Dahrendorf, publicado em língua inglesa sob o título Law and Order (1985). O livro compõe-se de quatro ensaios cujo objeto é uma reflexão sobre os dilemas, impasses e o futuro da ordem social e da liberdade em nossas sociedades contemporâneas. Apesar de publicado há dez anos (no Brasil, foi editado pelo Instituto Tancredo Neves, Brasília, em 1987), ele mantém sua atualidade. Chamou-me particularmente a atenção um dos temas predominantemente abordados no livro, qual seja, a erosão da lei e da autoridade. Mais do que isso, o fato de que Dahrendorf toma como pano de fundo para discutir esse "clássico tema" a generalização de um sentimento de insegurança e medo diante da escalada do crime na sociedade contemporânea. Vou destacar algumas das idéias contidas nos ensaios com o risco de
UNITERMOS:

anomia, autoridade, lei e ordem, violência, crime organizado, narcotráfico.
Professor do Departamento de Sociologia da FFLCH-USP 
ADORNO, Sérgio. Conflitualidade e violência: reflexões sobre a anomia na contemporaneidade. Tempo Social; Rev. Sociol. USP, S. Paulo, 10(1): 19-47, maio de 1998.

* Originalmente, este texto compõe, com alterações, o capítulo introdutório "Violência, crime e Justiça penal da sociedade brasileira contemporânea" de Adorno (1996).

Refiro-me basicamente a: As classes e seus conflitos na sociedade industrial (1982) e à coletânea de ensaios publicada no Brasil sob o título Sociedade e Liberdade, a maior parte deles redigido nas décadas de 1950 e 1960. Esse conjunto de trabalhos compreendem o que alguns comentaristas convencionaram nomear o "primeiro Dahrendorf" (cf. Izzo, 1991, p. 371-379).

2 Conviria aqui lembrar que, para Dahrendorf, o capitalismo é uma forma de sociedade industrial. Sua argumentação é justamente no sentido de esvaziar o conteúdo político do conceito de capitalismo, tal como ele foi elaborado no conjunto da obra de Marx. A este respeito, é célebre o embate com Ralph Miliband, autor de The state in capitalist society (1969). A tradução brasileira foi publicada pela Zahar, em 1972 ( $2^{\mathrm{a}}$ ed. em 1982). empobrecê-los, sobretudo porque se trata de um texto erudito, finamente argumentado, sedutor até.

Desde o início, ao anunciar seu objeto, o autor adverte que o objetivo de suas conferências não é uma contribuição para a criminologia ou para o debate sobre prisões e polícia. Como ele mesmo as qualifica, elas apresentam uma contribuição à análise do conflito social e da teoria política do liberalismo. Bem, é preciso de antemão entender o que Dahrendorf está compreendendo por conflito social na sociedade contemporânea. Nisto reside todo o empreendimento intelectual de sua obra. Em seus primeiros escritos, produzidos entre meados da década de 1950 e a primeira metade da década de $1970^{1}$, Dahrendorf inclinou-se a polemizar com as teorias de Parsons e de Marx. No que concerne ao sociólogo americano, seus escritos cuidaram de contestar os fundamentos que regem a teoria parsoniana do consenso social. Ao contestálos, Dahrendorf apontou para o sentido da construção de uma teoria do conflito social que lhe parece adequada para a compreensão de nossa contemporaneidade. Neste terreno, Dahrendorf mantém diálogo com a obra de Marx. Dahrendorf acolhe as concepções de Marx quanto à natureza do conflito de classes na sociedade industrial de seu tempo, isto é os conflitos predominantes no século XIX. No entanto, discorda que o modelo marxista seja aplicável à sociedade contemporânea, por esta entendendo-se as "formas de associação determinadas pela norma imperativa" desenvolvidas no curso do século atual. Referindo-se aos propósitos de seu estudo, afirma: “em primeiro lugar, desejo indicar certos modelos de desenvolvimento social que justificam a afirmação de que a teoria de classes de Marx é falsificada por observações empíricas. Em segundo lugar, no entanto, pretendo discutir características das sociedades industriais avançadas que devem ser levadas em conta por uma teoria do conflito e da mudança que pretenda ser aplicável não apenas às sociedades capitalistas, mas às sociedades industriais em geral" (Dahrendorf, 1982, p. 43)².

Seu principal argumento empírico é relativamente conhecido: o desenvolvimento industrial pós-Marx promoveu uma acentuada dissociação entre a propriedade e o controle dos meios de produção, cujos exemplos mais significativos repousam na proliferação de sociedades anônimas, de cooperativas e de empresas estatais, características típicas do século XX. A este fato seguiram-se imediatas consequiências, entre as quais: redução das distâncias entre gerentes e operários; isolamento dos proprietários da esfera da produção, esta cada vez mais sob controle dos managers; diferenciação de papéis entre proprietários e gerentes convertidas em diferenças entre acionistas e executivos; mudanças nas bases da legitimidade empresarial, antes ancorada nos direitos de propriedade, hoje em um tipo de autoridade que em muito se assemelha àquela que prevalece entre os diretores de instituições públicas; mudanças na composição da classe empresarial, cujo acesso é na atualidade possível não apenas através da herança, mas também por intermédio da construção de carreiras burocráticas alicerçadas na educação altamente especializada. De todas essas, a mais importante consequiência da decomposição do capital reside nas 
mudanças que operam na composição dos grupos sociais que participam dos conflitos, bem como nos problemas que os engendram e nos modelos de resolução que se desenvolvem.

Dahrendorf identifica cinco substantivas transformações que afetam a natureza dos conflitos e tensões na sociedade contemporânea. A primeira diz respeito às diferenciações no interior da classe trabalhadora, a qual perde no curso dos acontecimentos a homogeneidade que Marx identificara como tendência inexorável do desenvolvimento social e político dessa classe. Ao contrário, Dahrendorf anota progressivo crescimento de trabalhadores altamente qualificados, assemelhados a engenheiros e a trabalhadores de escritórios; crescimento de trabalhadores semi-especializados, porém com elevado grau de experiência industrial acumulada; e decrescente participação dos trabalhadores não totalmente especializados, a maioria deles nesta condição porque recém-chegados à indústria. Associada a este processo, Dahrendorf também observa a emergência de uma nova classe média -impensável no modelo marxista de classes sociais -, materializada no crescimento vigoroso dos trabalhadores de escritório. Trata-se de um agrupamento social que rigorosamente não pode ser conceituado como classe social, sequer como estrato social, cujo comportamento social e político é caracterizado pela ambigüidade justamente porque parte desses trabalhadores, os burocratas, se identifica com a burguesia, enquanto outra parte se identifica com a classe operária. Tudo isso tem, por conseguinte, efeitos decisivos sobre a natureza dos conflitos contemporâneos. Em terceiro lugar, as transformações sociais incidem sobre a intensificação da mobilidade social, entre e intra estratos sociais. Um novo modelo de alocação de papéis institucionaliza-se nas sociedades industriais contemporâneas, fruto da abertura de oportunidades oferecida pelo mercado. Em quarto lugar, pela primeira vez na história social moderna criam-se as condições para que a igualdade se efetive na prática. Nesse terreno, Dahrendorf apóia-se em Marshall (1967) para sustentar a existência de equalização de status na sociedade industrial contemporânea. Sob esta perspectiva, a notável expansão da igualdade social teria tornado as mudanças revolucionárias politicamente impossíveis. Em contrapartida, teria contribuído para alterar a substância dos conflitos de classe, reduzindo sua intensidade. Disto resulta uma quinta transformação, em verdade, uma das principais teses contidas na obra de Dahrendorf: a institucionalização dos conflitos sociais.

Ele argumenta que as lutas entre classes operárias e empresariado capitalista, típicas da Inglaterra entre fins do século XVIII e primeira metade do século XIX e típicas da Europa continental ao longo do século XIX, perderam sua intensidade e mesmo razão de ser, no século XX, em virtude da institucionalização dos conflitos. Por isto, Dahrendorf entende: por um lado, o reconhecimento da legitimidade do conflito de interesses e, por essa via, da legitimidade dos grupos em litígio; por outro lado, o estabelecimento de procedimentos e de mecanismos voltados para amortecer a violência dos choques tête-à-tête entre os grupos oponentes. No âmbito das relações industriais, ele 
Para os propósitos desta introdução, abstenho-me de apresentar as críticas que foram dirigidas contra essa interpretação do conflitos de classes na contemporaneidade elaborada por Dahrendorf. Além de Miliband, acima citado, conviria destacar as críticas de Antony Giddens (1984).

4 Este é considerado o segundo momento da obra de Dahrendorf. Sua preocupação central reside em refletir sobre a natureza dos conflitos contemporâneos, aqueles que gravitam em torno da legalidade, do poder e da autoridade. Compreende seus ensaios sobre liberdade, progresso, o novo liberalismo e, em particular, Law and Order, do qual me ocuparei em seguida. Vide também Darhrendorf (1992). refere-se ao desenvolvimento de negociações coletivas e aos sistemas de conciliação, mediação e arbitramento. No domínio da política, Dahrendorf sublinha que na atualidade órgãos legislativos e tribunais de justiça desempenham funções similares.

Dahrendorf conclui que os conflitos contemporâneos deixaram de gravitar em torno da distribuição escassa de recursos dentro de limites aceitos, para gravitarem em torno do contrato, ou seja lutas em que o objetivo principal é a lei e a ordem. Nessa linha de interpretação, o que passou a estar no cerne do jogo político é a maior ou menor capacidade de distintos grupos sociais influenciarem as estruturas normativas da sociedade. Em outras palavras, lutas em torno da desigualdade de poder e de autoridade. Assim, afirma: "tanto nas empresas industriais post-capitalistas quanto nas capitalistas, existem algumas pessoas cuja tarefa é controlar as ações de outros e emitir ordens e outras pessoas que devem deixar-se controlar e obedecer. Hoje, assim como há cem anos atrás, há governos, parlamentos e tribunais cujos membros têm a faculdade de tomar decisões que afetam a vida de muitos cidadãos, e há cidadãos que podem protestar e modificar seu voto, mas que têm de obedecer à lei. Na medida em que estas relações podem ser descritas como relações de autoridade, eu afirmaria que as relações de subordinação e dominação perduraram através das mudanças do último século. Acredito mesmo que podemos avançar ainda mais. A autoridade exercida tanto na sociedade capitalista quanto na post-capitalista é do mesmo tipo; nos termos de Weber, é uma 'autoridade racional' baseada 'na crença na legalidade das normas institucionalizadas e do direito de comando por parte daqueles que, através dessas normas, foram investidos com autoridade'. A partir desta condição seguem-se muitas outras, inclusive a necessidade de administração burocrática. Mas estas últimas baseiam-se, sobretudo, na desigualdade social fundamental da autoridade, que pode ser mitigada por seu caráter racional, mas que, não obstante, permeia a estrutura de todas as sociedades industriais e proporciona o determinante e a substância da maioria dos conflitos e choques" (Dahrendorf, 1982, p. 73)33.

Neste momento, a obra de Dahrendorf sofre um redirecionamento. Uma preocupação cada vez maior para com problemas de anomia na sociedade contemporânea. Trata-se de um problema, em sua concepção, relacionado ao progresso da liberdade, progresso esse materializado pela multiplicação das oportunidades de vida $a^{4}$ cujos elementos constitutivos são a liberdade de escolha, por um lado, e as ligaduras, ou seja os vínculos que atam os indivíduos à sociedade. "O advento da sociedade moderna significou incontestavelmente uma expansão das oportunidades de escolha, mas somente ao preço de desatar as ligaduras existentes" (Dahrendorf apud Izzo, 1991, p. 376-377). Esse é o contexto em que surge Law and Order. Nesta obra, Dahrendorf sustém sua interpretação do dilema da sociedade contemporânea: as lutas em torno do contrato são concomitantes a um processo reverso, qual seja, caminhamos inexoravelmente para a anomia, isto é, para a erosão da lei e da ordem, cujo principal indicador é a atual incapacidade do Estado de cuidar da 
segurança dos cidadãos e de proteger-lhes os bens. Em que se apóia essa constatação de Dahrendorf? Em fatos, mais propriamente, nas tendências mundiais ao aumento dos crimes e nas taxas sugestivas de uma retração na capacidade punitiva do Estado.

Segundo o sociólogo, desde a década de 1950 e mais dramaticamente ao longo dos anos 60, verificou-se um aumento substantivo dos crimes contra a pessoa. As taxas de assassinatos dobraram no período, especialmente nos Estados Unidos, Grã-Bretanha, Alemanha, Países Baixos e Suécia. A tendência para cima é ainda mais acentuada quando se fala em assaltos, roubos e estupros. Em trinta anos teria havido um aumento considerável do número de pessoas que vivem do crime, assim como um número crescente de vítimas. Vale dizer: primeiro, maior número de pessoas está violando as leis penais; segundo, maior número de pessoas figura como vítimas; terceiro, um universo considerável de comportamentos e bens protegidos pelas leis penais está cada vez mais vulnerável à ofensa e ao ataque. Ademais, em função mesmo da prosperidade e do aumento da circulação da riqueza, novas modalidades de crimes surgiram, como aquelas relacionados ao tráfico de drogas.

Em princípio, nada disso tem muita importância. Dahrendorf dirá mesmo que o problema em si não é o aumento dos crimes, porém a maior ou menor tolerância da sociedade em aceitá-los e conviver com eles. Ocorre que, na sociedade contemporânea, essa tolerância teria chegado a seu limite máximo, haja vista as reações e a ansiedade pública diante da crescente ameaça do crime. Essa ansiedade pública diz respeito, por conseguinte, aos significados que adquirem a erosão da lei e da ordem. Um desses significados aponta no sentido de que é hoje maior a probabilidade de um criminoso se manter oculto comparativamente ao passado. Dito de outro modo, há fortes suspeitas, embasadas em estatísticas, de que apenas uma pequena parcela dos crimes cometidos seja conhecida, problema para o qual concorrem muitos aspectos (alguns deles identificados no texto, como: descaso da polícia para com delinqüentes conhecidos, desistência deliberada de punições, afrouxamento das punições ou incapacidade de se lidar com as infrações).

Para Dahrendorf, ainda que se considere que ambos os fatos - isto é, crescimento dos crimes e crescimento das "cifras negras" (crime oculto) sejam conjunturais, e mesmo, que possam ser considerados dentro de uma normalidade qualquer, tais argumentos não elidem a existência de um problema real de lei e ordem na sociedade contemporânea, qual seja, se as violações das normas não são punidas de forma sistemática, elas se tornam em si sistemáticas. Atinge-se assim o campo traiçoeiro, porém fértil da "anomy", no entender de Dahrendorf não um estado de espírito, mas um estado da sociedade. A anomia é uma condição social em que as normas reguladoras do comportamento das pessoas perderam sua validade. Onde prevalece a impunidade, a eficácia das normas está em perigo. As normas parecem não mais existir ou, quando invocadas, resultam sem efeito. Tal processo aponta no sentido da transformação da autoridade legítima em poder arbitrário e cruel. 
Pois bem, para Dahrendorf, nas sociedades contemporâneas assiste-se ao declínio das sanções. A impunidade torna-se cotidiana. Esse processo é particularmente visível em algumas áreas da existência social. Trata-se de áreas onde é mais provável ocorrer isenção de penalidade por crimes cometidos. São chamadas de "áreas de exclusão", a saber:

1) nas mais diferentes sociedades, uma enorme quantidade de furtos não é sequer registrada. Quando registrada, é baixa a probabilidade de que o caso venha a ser investigado. O mesmo é válido para os casos de evasão fiscal, crime que parece ter instituído uma verdadeira economia paralela e para o qual há sinais indicativos de desistência sistemática de punição. Segundo Dahrendorf, a consequiência desse processo é que as pessoas acabaram tomando as leis em suas próprias mãos;

2) uma segunda área é afeta à juventude. Dahrendorf constata que em todas as sociedades modernas os jovens são responsáveis pela grande maioria dos crimes, inclusive os crimes mais violentos. No entanto, o que se observa é a tendência geral para o enfraquecimento, redução ou isenção de sanções aplicáveis aos jovens. Dahrendorf suspeita de que essa tendência seja em grande parte responsável pelo aumento da delinqüência juvenil;

3) uma terceira é o reconhecimento, por parte do cidadão comum, de espaços na cidade que devem ser deliberadamente evitados, isto é, o reconhecimento de áreas que se tornaram isentas do processo normal de manutenção da lei e da ordem. A contrapartida desse fato tem resultado no rápido desenvolvimento dos sistemas privados de segurança, o que se traduz na quebra do monopólio da violência em mãos dos órgãos e indivíduos autorizados. Para Dahrendorf, se levado ao extremo esse processo conduz necessariamente à anomia parcial;

4) uma quarta área de exclusão diz respeito à própria falta de direção ou orientação das sanções. Para o sociólogo alemão, quando a extensão das violações às normas se tornaram bastante vastas, sua conseqüente aplicação se torna difícil, por vezes impossível. Motins de ruas, tumultos, rebeliões, revoltas, insurreições, demonstrações violentas, invasões de edifícios, piquetes agressivos de greve e outras formas de distúrbios civis desafiam o processo de imposição de sanções. Não há como distinguir atos individuais de protesto maciço de autênticas revoluções, manifestações coletivas de uma exigência de mudança.

Bem, penso que a exposição, até aqui realizada, recoloca as principais idéias e argumentos de Dahrendorf no primeiro de seus ensaios. Não vou deter-me nos ensaios seguintes, embora eles sejam tão importantes para a "arquitetura" argumentativa de sua proposta de reconstrução da sociedade contemporânea quanto o capítulo inicial do livro. Permito-me, contudo, fazer algumas menções e tecer algumas considerações na medida em que elas encaminham na direção de minhas reservas quanto às interpretações de Dahrendorf a respeito dos fatos sociais contemporâneos.

No segundo ensaio, intitulado "Buscando Rousseau, encontrando Hobbes", Dahrendorf anuncia sua proposta. Retomando e ampliando suas idéias, ele afirma que o mundo contemporâneo é caracterizado tanto pelo en- 
fraquecimento das sanções penais quanto pelo enfraquecimento das "ligaduras" (isto é, liames sociais que transcendem mudanças culturais de curto prazo). Esse duplo processo deixou vestígios em fatos, entre os quais a reforma do direito penal alemão no início dos anos 60. Dahrendorf critica as propostas "alternativas" que vingaram na reforma e introduziram uma nova política criminal que advogava a recusa das penas que "dessocializam" o homem, tais como as de prisão, princípio que, em última instância, entendia o criminoso como ser carente de cuidados e não sequioso de punições. De acordo com a análise de Dahrendorf, o efeito prático dessas concepções, aplicadas ao direito penal, foi a de enfraquecimento das sanções até às raias da impunidade. $\mathrm{Na}$ mesma direção, detém-se nas concepções de Habermas sobre a estrutura normativa da sociedade, aproximando-o das concepções contidas em Emílio e, por essa via, qualificando-o como o "Rousseau contemporâneo". Opondoo às imagens de homem contidas no pensamento de Kant, conclui afirmando que o grande perigo da contemporaneidade é justamente a "impossibilidade de sustentar a sociabilidade insociável do homem". Por isso, as soluções para esse mundo passam necessariamente pela reconstituição do contrato, vale dizer, dos liames indispensáveis ao funcionamento do contrato. Em síntese, sua proposta reside na (re)construção de instituições ${ }^{5}$.

No terceiro ensaio, intitulado "A luta pelo contrato social", Dahrendorf cuida de contextualizar sua proposta. Para tanto, detém-se em um dos temas mais presentes em sua sociologia: os novos antagonismos da sociedade industrial. Após uma análise do processo histórico de institucionalização ou "democratização" dos conflitos sociais, ele vai identificar suas conseqüências em tripla direção: primeiro, o fracasso do Welfare State (Estado social) como mecanismo de transferência de recursos para garantir a efetividade dos direitos de cidadania para todos; segundo, a emergência de uma nova pobreza constituindo sete grupos principais (desempregados, idosos, famílias monoparentais, doentes e incapazes, os de baixa renda, mulheres solteiras com dependentes mais velhos e pobres internados em instituições). Todos eles extremamente dependentes de mecanismos de transferência de renda e, mais vulneráveis, incapazes de se defenderem das reduções dos benefícios do Estado social. Terceiro, uma nova explosão de litigiosidade, não mais entre patrões e empregados ou entre ricos e pobres, porém entre a "classe majoritária", aqueles que estão empregados e usufruem os direitos de cidadania, e as "classes inferiores", compostas de indivíduos excluídos dos direitos e considerados dispensáveis (aqueles que não dispõem de cidadania, como os imigrantes; aqueles que já a dispuseram, mas não mais a possuem na sua totalidade, como os idosos; e aqueles que ainda não dispõem e que encontram enormes dificuldades de acesso aos direitos, como os jovens).

A conclusão deste ensaio caminha no sentido de sugerir que esses conflitos instituem crises de legitimidade nas sociedades contemporâneas, por isso entendendo-se sua incapacidade de fomentar lealdade a seus valores básicos. Daí porque a questão do contrato teria se tornado dominante. É em torno
5 Nunca é demais lembrar que conclusões desta ordem se encontram igualmente na obra de Durkheim, especialmente em A Divisão do Trabalho Social (1963) e em A Educação Moral (1965), bem como em Mannheim, particularmente em Essays on sociology and social psychology (1953). 
6 Aqui Dahrendorf faz menção às obras de John Rawls (1971) e de Nozick (1974).

7 Certamente, com fundamento em argumentos extraídos de Foucault (1966), seria possível contestar essa espécie de subjetividade referida à "sociabilidade insociável do homem", solo no qual Dahrendorf sustém sua concepção de "ligaduras". Embora devesse fazê-lo, porquanto se constitua em elemento nuclear em sua arquitetura argumentativa, optei por concentrar minhas reflexões em torno da questão da anomia, como se verá a seguir.

8 É justamente nos fundamentos liberais da sociologia de Dahrendorf que se encontram, em meu ponto de vista, um de seus maiores obstáculos. De fato, embora o sociólogo alemão pretenda descrever e explicar sob a perspectiva sociológica os problemas contemporâneos, isto é, aqueles pertinentes ao nosso século, e conquanto se in- dela que reside a alternativa proposta por Dahrendorf no sentido de um liberalismo radical cuja agenda incluiria enfrentar três problemas básicos: a inserção dos jovens, o futuro do trabalho e o problema da lei e da ordem. Quanto a este último, a proposta não pode se restringir ao velho remédio rousseuniano e sequer ser substituído por políticas econômicas voltadas para uma justiça distributiva. Segundo Dahrendorf, o reconhecimento de que a escalada do crime tem profundas raízes sociais, ligadas à falência do Estado social (Welfare State), não conduz necessariamente a advogar isenção de sanções para os criminosos procedentes dos estratos mais pobres da população. Por liberalismo radical, entende-se, por conseguinte, uma nova atitude perante às instituições, atitude firme e ao mesmo tempo moderada.

Por fim, o último ensaio, intitulado "A sociedade e a liberdade" (aliás, não poderia ser diferente), cuida de apresentar a proposta desse liberalismo radical. Adestacar, três aspectos. Primeiro, um argumento de fundo que sempre esteve presente ao longo de toda a "arquitetura argumentativa" do texto. Indaga o autor: por que defender as instituições? Sua resposta é simples e direta, embora suscite não poucos problemas. Trata-se de assegurar a sociabilidade insociável do homem, base sob a qual as instituições configuram criações humanas voltadas para a efetivação dos direitos do homem e para o controle sistemático do poder. Daí, a possibilidade de liberdade.

Um segundo aspecto diz respeito ao fato de que, em termos de políticas públicas, sua proposta incide nas "áreas de exclusão" anteriormente assinaladas. Em linhas gerais, ele sugere intervenção nas seguintes direções: (a) punir crimes atualmente não punidos; (b) ampliar o leque de oportunidades para os jovens, mas também exigir-lhes rigoroso respeito à autoridade; (c) apoio às instituições de lei e de ordem, mediante estreitamento dos laços entre polícia e comunidades locais, o que, em última instância, significa conferir uma abordagem institucional ao problema da lei e da ordem.

Um terceiro aspecto, por fim, está relacionado, a uma espécie de atributo que ele agrega à sua proposta de liberalismo radical. Trata-se de uma proposta que deve evitar tanto a anomia quanto a hipernomia (excesso de normas ameaçando sufocar toda iniciativa e liberdade). Essa "bête noire" aponta para a necessidade de uma visão sobre o mínimo de respostas normativas e institucionais que o contrato social pode fornecer. Esse mínimo diz respeito à "justiça com eqüidade", o que significa dizer que a justiça não está ausente da construção normativa da sociedade.

Creio que esse desenvolvimento encerra o debate instituído pelo texto de Dahrendorf. Em meus comentários, vou privilegiar algumas questões em detrimento de outras, por mais interessantes e relevantes que possam ser principalmente para a teoria sociológica contemporânea. Por exemplo, vou deixar de lado um dos alicerces epistemológicos do texto sobre o qual se edifica a arquitetura argumentativa de Dahrendorf. Refiro-me à "sociabilidade insociável do homem", princípio que sustém suas concepções de contrato so- 
cial, conflitos, anomia e hipernomia etc. Trata-se de um princípio seguramente inspirado na metafísica kantiana e que me parece propor problemas insolúveis ${ }^{7}$. No mesmo sentido, não vou me ocupar detidamente de uma crítica aos limites postos pelos fundamentos liberais da sociologia de Dahrendorf, embora não se possa ignorá-los quando menos por suas implicações teóricas ${ }^{8}$.

Eu gostaria, no entanto, de começar por uma pequena observação, à margem do texto, para em seguida questionar-lhe os fatos. O que me parece estranho é uma espécie de nonsense histórico que percorre o raciocínio e os argumentos de Dahrendorf. Por um lado, o texto propõe-se a abordar os novos antagonismos da sociedade contemporânea, nuclearizados em torno das lutas pelo contrato social, os quais remetem a problemas de efetivação da lei e da ordem. Para tanto, recorre com frequiência ao contraste entre passado e presente, seja comparando as lutas sociais dos séculos XVIII e XIX com as do século atual, seja comparando a evolução da criminalidade e das sanções, por exemplo, nos últimos trinta anos. Essa comparação é sempre feita a partir de um olhar que, do passado, vê o presente. Ao fazê-lo, vê o presente em crise, ora como crise de legitimidade (em relação às normas), ora como crise de autoridade (em relação ao poder de impô-las). A imagem flagrante do texto é a de decadência. Daí, os perigos disseminados por todo o tecido social: crime em excesso criando situações sociais intoleráveis, sanções não-aplicadas, geração de "áreas de exclusão" etc.

O tratamento dos problemas contemporâneos nesses termos supõe um anacronismo histórico, qual seja, o de buscar inspiração no passado para compreender o presente ${ }^{9}$. Disso resulta inevitavelmente um paradoxo: a recuperação de uma linguagem típica de fins do século XIX para reconstruir fatos contemporâneos. Assim é que se fala em anomia, crise de autoridade, erosão da lei, recuperação das instituições, tudo lembrando o universo sociológico durkeimiano, forjado àquela época para dar conta dos elementos anômicos da divisão social do trabalho. Não é por acaso também que esses temas sejam empiricamente tratados sob os mesmos signos que sociólogo francês reservara para dar conta daqueles elementos anômicos, como sejam o crime e o sistema de sanções. Como apontam Lagrange \& Roché (1993), há uma impressionante associação entre as linguagens de fins do século XIX e fins do século XX. Nelas, o crime ocupa a face dianteira da cena pública: converte-se em inquietação coletiva, em objeto de interesse por parte dos analistas e em alvo da moralidade pública e dos princípios da organização social, a despeito de os contextos sociais e políticos que marcam ambos períodos não serem comparáveis.

Desde fins do século XIX, diferentes observadores - jornalistas, literatos, historiadores, sociólogos, artistas - da sociedade francesa vincularam o fim do século passado a uma era de degradação da ordem e da segurança, simbolizadas pela degenerescência racial, pelos vícios morais, pela degradação dos valores, pela difusão de perturbações mentais de toda sorte. Analistas como Joly e Tarde (apud Lagrange \& Roché, 1993) constatam que a cline a adequar a teoria liberal à atualidade, sua concepção de liberalismo é a mais convencional possível, detendo-se em sua caracterização social e política tal como essa doutrina filosófica foi pensada no século XIX, no auge do capitalismo concorrencial.

9 Neste domínio, minha inspiração baseia-se no excelente e clássico estudo de Mannheim: "O pensamento conservador", capítulo integrante de Essays on sociology and social psychology, citado. Neste ensaio, Mannheim afirma que "o pensamento conservador se concentra sobre o passado na medida em que o passado sobrevive através do presente; (...) Ver as coisas autenticamente como um conservador é experimentar os acontecimentos em termos de uma atitude derivada de circunstâncias e situações ancoradas no passado" (Mannheim, 1980, p. 125-126). 
criminalidade vinha aumentando muito rapidamente desde o início do século XIX. Mais do que a gravidade dos crimes, o que os preocupava era o crescente volume da pequena delinqüência, fenômeno interpretado como resultante de um relaxamento dos costumes. "Os criminólogos tem a impressão de uma transformação radical da sociedade, rápida e violenta. Os quadros sociais e psicológicos vêm abaixo. Muitas rupturas se conjugam impedindo que a estabilidade necessária se realize. A sociedade, pensada como um organismo, está doente, e as doenças são contagiosas. O perigo é tanto mais intenso quanto se multiplicam na sociedade moderna os contatos que favorecem a difusão das condutas criminais. Entre as inquietações deste final de século, os criminólogos retêm principalmente algumas delas. Trata-se do que se poderia resumir sob a idéia de uma morte das comunidades: a família, o vilarejo, a autoridade da Igreja e do governo" (Lagrange \& Roché, 1993, p. 85-86).

Na cidade, o crime converte-se em atividade racional, pressupondo um cálculo de custos e benefícios. Daí que migrar do campo para a cidade destrói as referências territoriais e morais. Como apontava Joly, a emigração periódica conduzia primeiro à vagabundagem, depois à delinquiência. Lagrange e Roché sublinham que o anonimato das multidões urbanas não somente atraiu a atenção dos criminólogos, mas também de sociólogos do início do século XX, como Weber, Tönnies, Durkheim e Simmel, todos impressionados com o aparecimento dessa nova figura da vida social: o outro, esse desconhecido. Na mesma direção, criminólogos criticam a "crise" da família. Sustentam que, quando a família claudica, o crime se expande. De modo geral, manifestaramse preocupados com as "desventuras" da instituição familiar: a diminuição do número de seus membros, a dissolução dos laços do casamento, os abortos. Para muitos, o divórcio tinha o mesmo estatuto moral do suicídio e do crime. Finalmente, os criminólogos responsabilizam os conflitos políticos pela elevação acentuada dos crimes. Mais particularmente, o que está no cerne do debate é a natureza do governo democrático, cuja dinâmica política, dissensual por excelência, é considerada carente de estabilidade e de elites moderadas. Suas raízes reportar-se-iam à Revolução Francesa. Na leitura de Tarde, o egoísmo e as pulsões revolucionárias explicariam a estatística criminal. Na leitura de Joly, quanto mais se avança no século, mais a autoridade se desorganiza. A presença das multidões na arena política corromperia a sociedade, a escola e os sindicatos (cf. Lagrange \& Roché, 1993, p. 83-98).

Ainda que se possa reconhecer a agudez de Durkheim e de seus contemporâneos Tarde e Joly no diagnóstico dos problemas da sociedade moderna, não há como deixar de reconhecer também as pronunciadas diferenças entre a sociedade por eles observada e a sociedade contemporânea. Com isso estou argumentando que, para serem compreendidos, os fatos contemporâneos precisam ser vistos senão com os olhares da contemporaneidade. Reporto-me aqui a uma passagem de Foucault tão sugestiva quanto enigmática. Em Vigiar e punir, comentando a atualidade das revoltas nas prisões em todo o mundo e justificando seu interesse pela história das prisões, ele afirma: "É 
desta prisão, com todos os investimentos políticos do corpo que ela reúne em sua arquitetura fechada, que eu gostaria de fazer a história. Por puro anacronismo? Não, se entendemos com isso fazer a história do passado nos termos do presente. Sim, se entendermos com isso fazer a história do presente" (Foucault, 1977, p. 32). Essa passagem oferece uma idéia do modo pouco convencional como Foucault aborda a história, os fatos pretéritos e o presente. Nessa passagem, Foucault parece fazer menção ao anacronismo de nossos procedimentos usuais e habituais de reconstrução histórica, nos quais o passado é lido, reconstruído, perquirido, vasculhado com vistas a explicitar o presente e iluminar os caminhos do próprio curso histórico. Sob essa perspectiva, passado, presente e futuro encontram-se inexoravelmente atados, cabendo ao historiador explicitar seu sentido e direção. Trata-se em última instância de uma história circular. Não no sentido que se lhe atribuíam na antigüidade clássica (de uma circularidade determinada pelo movimento natural da vida e da morte, na busca incessantemente renovada da eternidade); porém no sentido de um eterno retorno às origens. Assim, tudo está previamente dado e, por essa via, a explicação é uma espécie de profecia que se auto-realiza. $\mathrm{O}$ anacronismo resulta, portanto, da eterna repetição do mesmo. Não há lugar para o acontecimento. A história não é a atualidade do presente, do novo, do inesperado, do inaudito, do que muda e do que é mudado. Penso que nesta passagem Foucault aponta para uma das mais espinhosas questões da epistemologia das ciências sociais: não existem fatos objetivos, porém construções históricas, as quais, acrescentará ao longo desse livro, estão imersas em um regime de verdade e de poder.

Ora, se assim é, o que está justamente em causa no texto de Dahrendorf é a atualidade e contemporaneidade dos fatos narrados como objetivos. Ao contrário, os fatos apontados consistem em construções históricas e culturais, dependentes portanto dos regimes de poder e verdade em jogo, os quais, por isso mesmo, constroem nossa contemporaneidade. Por isso, é possível opor às interpretações de Dahrendorf outras interpretações, fatos contra fatos, para ao final perguntar o principal: qual é, enfim, o regime de poder e verdade subjacente e que sustém a atualidade das "demandas" contemporâneas por ordem social. Isso é o que se procurará explorar e responder mais à frente. Por ora, contentemo-nos em questionar-lhes os fatos.

Diferentes analistas concordam que, após uma período longo de relativa estabilidade (1860-1950) nas taxas de criminalidade, tenha se verificado, em diferentes sociedades, fortes tendências para o crescimento dos crimes. Ao que tudo indica, essas tendências manifestaram-se inicialmente nos países de língua inglesa e tradição anglo-saxã, estendendo-se pouco a pouco para os países de tradição católica, inclusive aqueles situados na América Latina (cf. Robert \& Van Outrive, 1993; Robert et alii, 1994; Weiner \& Wolfgang, 1985; Wright, 1987). Não vem ao caso mencionar cifras para contrapô-las às apresentadas por Dahrendorf. No entanto, não há como deixar 
${ }^{10}$ Os problemas metodológicos e os cuidados no tratamento científico dos dados coletados em pesquisas de vitimologia encontram-se descritos em Cohen (1974), Gove et alii (1985) e, mais recentemente, em Robert \& Zauberman (1995). de trazer o debate para o âmbito da sociologia criminal (ou da criminologia como queriam alguns), justamente uma área que aquele autor procurou evitar. E por quê? Porque, a despeito das convergências entre as afirmações de Dahrendorf e as de especialistas, há inúmeras ponderações que não podem ser ignoradas e das quais se cercam os pesquisadores experimentados.

De fato, essas avaliações são feitas a partir dos crimes conhecidos, isto é, dos crimes detectados e registrados pelas agências encarregadas de controle da ordem pública e de contenção da delinquiência. Há transgressões que não chegam ao conhecimento da autoridade pública. Entre o conhecido e o desconhecido, há um gap que, na literatura especializada, se convencionou chamar de cifras negras. Qual a extensão desse gap? Bem, pouco se sabe de concreto. Desde há duas décadas vêm se aperfeiçoando as chamadas pesquisas vitimológicas através das quais se busca examinar o movimento da criminalidade da perspectiva das vítimas e ao mesmo tempo mensurar o gap. Os procedimentos metodológicos são altamente sofisticados, porém enfrentam obstáculos sérios porque lidam fundamentalmente com a memória das vítimas. Essa a razão porque os resultados ainda têm que ser vistos com algumas reservas ${ }^{10}$. Para se ter uma idéia, no que concerne à condução de veículos sob efeitos do álcool, um instituto de pesquisas sobre o tráfico observou, há alguns anos, que apenas 1 caso entre 20 mil era conhecido pela polícia. Talvez essas taxas sejam análogas no que concerne ao uso de drogas ilícitas. Nos Países Baixos, sabe-se que o volume de denúncias de violência em locais públicos corresponde a cerca de $20 \%$ de todos os casos verificados. Assim, não se tem bases científicas, fidedignas, para confirmar que tenha havido de fato um aumento da criminalidade nos últimos trinta ou quarenta anos. Pode ser que as tendências observadas reflitam outro tipo de comportamento: maior inclinação dos cidadãos em denunciar os crimes de que foram vítimas. Isso sugere, por conseguinte, que o sentimento de insegurança e medo diante do crime e o desejo de mais punições, em especial punições mais rigorosas, parecem responder por outras inquietações que vão além do domínio da delinquiência.

Mas há outros aspectos dignos de reparos. Dahrendorf estabelece uma sorte de conexão direta entre o aumento dos crimes e o enfraquecimento ou isenção de punições. Estabelece, por conseguinte, uma relação de causalidade entre fatos diversos. Uma coisa é o aumento dos crimes. Ele pode estar relacionado a diversas causas, como mudanças no comportamento delinqüente, mudanças no comportamento das vítimas ou dos cidadãos comuns, mudanças nas formas habituais de sociabilidade com repercussão sobre os ilegalismos e sobre os próprios objetos da delinqüência (cf. Foucault, 1977). Já a distribuição de sanções é função dos dinamismos do aparelho penal, em particular dos nexos entre as agências policiais, as agências de acusação (Ministério Público), os tribunais de justiça e o complexo prisional, bem como do empenho das autoridades em apurar os crimes. Assim, o crescimento dos crimes pode ser ou não acompanhado de um crescimento de sanções, por mais desejável que seja a correspondência entre ambos crescimentos do ponto de 
vista social e político.

Além do mais, há que se anotar duas constatações feitas pelos especialistas que contrariam sobremodo os fatos objetivos com que Dahrendorf pretende caracterizar a erosão da lei e da ordem na sociedade contemporânea. Primeiro, os estudos são unânimes em mostrar uma forte tendência, desde o século passado, na estatização do controle penal e da sanção (cf. Cusson, 1990), tendência que nada tem a ver com outra tendência contemporânea que é a da privatização dos serviços de segurança, melhor dizendo, dos serviços de prevenção e vigilância contra o crime, cujo dinamismo atende aos estímulos de mercado (cf. Erbès, 1990-1991; Ocqueteau, 1988, 1990-1991; Ocqueteau \& Pottier, 1995). Se as taxas de condenação à pena de prisão estão em declínio, isso não significa um afrouxamento dos controles penais ou do sistema de sanções; antes, deve-se à relativa diminuição da pena de supressão da liberdade no conjunto do arsenal penal. De qualquer forma, tem-se observado em contrapartida um aumento das taxas de encarceramento, prática sob o encargo da polícia. Em segundo lugar, não é verdade que as penas tenham sido amortecidas ou suavizadas nas democracias ocidentais. Estudos demonstram que nos Estados Unidos, Inglaterra e Países Baixos as tendências têm se inclinado para a maior severidade das penas, nas duas últimas décadas (cf. Hulsman, 1990; Wacqüant, 1996).

Nessa mesma direção, é altamente discutível a maior contribuição dos jovens para o aumento da criminalidade. É bem que verdade que, em distintas sociedades, a delinqüência juvenil adquire maior ou menor gravidade, podendo mesmo contribuir de modo acentuado para a criminalidade, em especial a de tipo violento. Nunca é demais lembrar que o envolvimento dos adolescentes com a criminalidade adulta suscita desafios agudos às políticas de proteção e prevenção. Seja o que for, não há nenhuma evidência empírica fidedigna de que aquela tendência venha se generalizando e se tornando dominante, como pretende Dahrendorf. De igual modo, não é aceitável o argumento segundo o qual há, nas sociedades contemporâneas, forte inclinação para proteger os jovens delinqüentes, isentando-os da aplicação de sanções. Diversos estudos mostram que as tendências da legislação da infância e da adolescência, perfilando a orientação de organismos normativos internacionais, têm sido no sentido de evitar abusos na aplicação de medidas ou na distribuição de sanções. Essa exigência requer da parte dos agentes encarregados de implementar normas estatutárias o discernimento rigoroso de situações, determinando-se medidas diferenciadas segundo a gravidade das infrações, as quais inclusive prevêm limitação de direitos e supressão de liberdade. Além do mais, em não poucos países, a maioridade penal ocorre aos quinze ou dezesseis anos, fazendo com que muitos jovens estejam, ainda adolescentes, sujeitos aos rigores da legislação penal aplicável aos adultos (cf. Lahalle et alii, 1994) $)^{11}$.

Resulta desses questionamentos uma indagação inevitável: por que uma reação punitiva seria mais adequada do que respostas não punitivas para
${ }^{11}$ De igual modo, não se pode ignorar os argumentos defendidos por demógrafos segundo os quais atravessamos uma era de "onde jovem" com profundas repercussões no comportamento coletivo, das quais não está excluída uma maior incidência de crimes juvenis. A respeito, vide sugestivo estudo de Bercovich, Dellasoppa e Ariaga (1997). 
os problemas de conflitualidade e litigiosidade das sociedades contemporâneas? Por que o desejo obsessivo de punir, de punir mais e sempre com maior intensidade? Bem, pretendo avançar algo nessa direção a seguir.

Retomando a exposição anterior, pode-se dizer, perfilando Dahrendorf, que o crescimento da criminalidade e o suposto aumento da impunidade resultam na erosão da lei e da ordem nas sociedades contemporâneas. O Estado aparece como incapaz de cuidar da segurança dos cidadãos e de proteger seus bens, materiais e simbólicos. No cerne da "demanda por ordem" aloja-se não apenas o sentimento de que o passado se perdeu inexoravelmente pela avalanche do "progresso" histórico, sentimento simbolizado nas imagens de pânico moral proporcionados pela concentração urbana, pela "crise" da família, pela irrupção das multidões na arena política. A perda é sentida como ausência de solidariedade, de esgarçamento dos vínculos morais que conectam indivíduos às instituições, ausência sacramentada pelo definhamento da autoridade. Tudo se passa como se os interesses egoístas suplantassem o bem comum. Seu sintoma, a explosão de litigiosidade entre o indivíduo e a sociedade, tão bem descrita por Durkheim em inúmeras de suas obras, resultaria na desobediência civil, na perda desse sentimento segundo o qual “agir bem é obedecer bem" (Durkheim, 1963, apud Fernandes, 1994, p. 83).

Ademais, no cerne da "demanda por ordem" está paradoxalmente a reivindicação de "mais legalidade", porém no contexto de aguda crítica ao Estado democrático de Direito. Na verdade, o que se reivindica não é a lei como princípio de limitação do poder arbitrário ou de instrumento de garantia de direitos; contudo, a lei como veículo de imposição autoritária da ordem, numa palavra de punição. Por isso, ao questionar o conservadorismo que subjaz à leitura de Dahrendorf quanto ao cerne dos problemas contemporâneos, busquei questionar-lhe os fatos. Não apenas censurei-lhe sua leitura conservadora da história, como meus argumentos podem ser resumidos em quatro proposições: primeiro, a constatação de um aumento da criminalidade, nos últimos trinta anos, é matéria controvertida; segundo, não há per si uma relação de causalidade entre o movimento da criminalidade e o movimento das punições; terceiro, não se constata uma tendência para a suavização dos sistemas de sanções, como pretende Dahrendorf; quarto, na mesma direção, não se sustém o argumento de que os jovens venham sendo beneficiados com uma legislação punitiva branda, a despeito do crescimento da delinqüência juvenil.

A esses argumentos poder-se-ia acrescentar outros. Nunca é demais lembrar que, a despeito dos avanços globais conquistados em termos de respeito dos direitos humanos, nas três últimas décadas, as forças repressivas tenderam a se tornar mais agressivas e mesmo violentas no enfrentamento do crime. Isso é tanto mais verdadeiro em sociedades com forte tradição autoritária, onde vigem regimes políticos não-democráticos ou que se encontram em processo de transição democrática (cf. O’Donnell, 1988; Pinheiro, 1991). Um outro aspecto a ser considerado é que Dahrendorf, ao eleger a erosão da lei e 
da ordem como o cerne do problema contemporâneo, não se inclina a indagar sobre os múltiplos significados da lei e dos direitos para diferentes grupos sociais. No Brasil, por exemplo, sabe-se através de alguns estudos e pesquisas que as diferentes classes sociais não se sujeitam igualmente à obediência dos estatutos legais sob qualquer princípio moral ou ético fundado na convivência política pacífica. Terceiro, parte substantiva das propostas apresentadas por Dahrendorf, enfeixadas em torno do que ele nomeia de liberalismo radical, encerram as soluções dos problemas contemporâneos nos marcos de uma reforma institucional tendente, seja a conferir maior racionalização aos serviços públicos de segurança pública, seja a estreitar os laços entre os cidadãos e sua polícia. Em outras palavras, parte das soluções (insisto em sublinhar parte porque Dahrendorf sublinha outras que não se limitam ao âmbito da reforma institucional) gravita em torno da maior eficácia operacional das agências de controle da ordem pública. Ora, não há quaisquer garantias de que reformas institucionais, por mais desejáveis que sejam, possam baixar as taxas de criminalidade e, por essa via, oferecer ao cidadão comum o sentimento de que tem seus bens, materiais e simbólicos, protegidos.

Impõe-se assim retirar o debate sobre a criminalidade urbana e suas formas de contenção do campo onde ele se confinou, há cerca de duas décadas, e persiste confinado. Cuida-se de problematizar" a "demanda por ordem" que se encontra presentemente quer nas falas do cidadão comum, quer das autoridades encarregadas de formular e implementar políticas públicas penais, falas freqüentemente veiculadas pela imprensa escrita e pela mídia eletrônica e que inclusive não se encontram ausentes do debate acadêmico e do discurso científico. Nas acres crônicas da insegurança e do medo do crime, nos fatos e acontecimentos que sugerem a fragilidade do Estado em velar pela segurança dos cidadãos e proteger-lhes os bens, materiais e simbólicos, nos cenários e horizontes reveladores dos confrontos entre defensores e opositores dos direitos humanos, mesmo para aqueles encarcerados, julgados e condenados pela justiça criminal, tudo converge para um único e mesmo propósito: o de punir mais, com maior eficiência e maior exemplaridade. Trata-se de propósito que se espelha em não poucas demandas: maior policiamento nas ruas e nos locais de concentração populacional, sobretudo as habitações populares consideradas celeiro do crime e de criminosos; polícia menos tolerante para com os criminosos; justiça criminal menos condescente com os "direitos" dos bandidos e mais rigorosa na distribuição de sanções penais; recolhimento de todos os condenados às prisões que devem se transformar em meios exemplares de punição e disciplina. Com nuanças entre os mais radicais, que advogam pena de morte e imposição de castigos físicos aos delinqüentes, e os mais "liberais", que pretendem o aperfeiçoamento dos instrumentos legais de contenção repressiva dos crimes, todos gravitam em torno de um imperativo categórico: o obsessivo desejo de punir.

Um empreendimento desta ordem requer retomar o debate no mesmo terreno em que ele havia sido circunscrito por Dahrendorf; isto é, o terreno

\footnotetext{
${ }^{12} \mathrm{O}$ termo reporta-se a Foucault, para quem o conceito diz respeito a uma "análise dos 'jogos' de verdade, dos jogos entre o verdadeiro e o falso, através dos quais o ser se constitui historicamente como experiência, isto é, como podendo e devendo ser pensado" (Foucault, 1984, p.12).
} 
dos conflitos e da litigiosidade na sociedade contemporânea. Porém, uma retomada que enseja advertências. Uma primeira advertência: nas sociedades contemporâneas não há mais espaço para pensar conflitos numa versão liberal. Como se sabe, o pensamento liberal tende a privatizar conflitos cuja origem é social. Os conflitos são vistos como conflitos entre indivíduos entre si, entre indivíduos e sociedade, entre indivíduos e Estado. Não é sem motivos que a problemática do crime e da punição tenha ocupado tanta atenção dos sociólogos liberais. No registro liberal, essa problemática diz respeito ao confronto entre a consciência coletiva (consciência de um imperativo categórico, a sanção) e a consciência individual, materializada em torno da responsabilidade penal do criminoso. Dificilmente, fatos contemporâneos como racismo, genocídio, exclusão, narcotráfico configuram modalidades de conflito e litigiosidade enquadráveis nos estreitos limites ditados pela visão liberal. Portanto, é preciso pensar esses fatos tendo por eixo não o indivíduo, porém coletivos.

Uma segunda advertência: queiramos ou não, é preciso ter claro que os fatos constituem narrativas sociais que instituem em determinados momentos históricos, por exemplo, em conjunturas particulares, um certo arranjo de formas de solidariedade, de reciprocidade e de conflito. Trata-se de um arranjo precário, dependente do confronto e direção que tomam as forças sociais em gravitação no interior de um campo determinado (social, político, cultural), precário porque sempre sujeito a ser rearranjado e rearmado. Isso significa que, para compreender fatos, como os fatos contemporâneos, é preciso adotar uma atitude nominalista, evitando-se sejam as tentações metafísicas - como a busca de um fio condutor último, como a sociabilidade insociável do homem (Dahrendorf) -, sejam as inclinações no sentido de atribuir estatuto de cientificidade às interpretações (cf. Foucault, 1979). Nominalismo significa antes de tudo trazer os fatos à superfície da sociedade, isto é, fazê-los emergir no torvelinho de práticas e representações, sem menção a um sujeito demiurgo ou a intenções excusas que se escondem por detrás dos próprios fatos.

É nestes termos que se pretende trazer para o debate um fato contemporâneo: o crime organizado e, em especial, uma de suas modalidades, qual seja, o narcotráfico. Em que medida o crime organizado é um fato contemporâneo? Se não, em que consiste sua contemporaneidade?

Seguramente, o crime organizado não é uma invenção recente. Ao que parecem sugerir estudos históricos, seus rudimentos podem ser buscados nos bandos milenaliristas que proliferaram pela Europa Central, Itália e Espanha desde a Idade Média. Sua versão moderna está profundamente marcada pelas organizações da Itália meridicional, em particular a Cosa Nostra, pelas organizações do sul da França (Marselha e Córsega) em fins do século XIX e início do XX, e sobretudo pelas organizações americanas sediadas em Chicago e Nova York entre as décadas de 1910 e fins da década de 1930. Muitas das características que hoje se observam no crime organizado já esta- 
vam de fato presentes naquelas formas anteriores de organização delinqüiente. Por exemplo, características como: recrutamento preferencial de jovens; valor atribuído à posse da arma de fogo, donde decorre uma disposição gratuita para matar; monopólio altamente concentrado das atividades criminais; estruturas de mando rigidamente hierarquizadas e personalizadas, reatualizadas por rituais precisos e codificados segundo normas particulares e regidas pelo segredo; manutenção de milícias particulares em moldes militarizados; fixação de uma rede de informantes e espias. Nesse conjunto de práticas, lugar estratégico é conferido à corrupção. Sem a cumplicidade dos agentes públicos, sem o estabelecimento de conluios entre o crime organizado e segmentos da burocracia estatal, certamente as atividades não teriam se expandido como de fato se expandiram, ainda que em ondas não sucessivas.

Desde o esclarecedor estudo de Hobsbawm (1959, ed. bras.1970), sabe-se que o florescimento das máfias é fenômeno social recente, datando do século XIX. Compreendem distintas formas de ação e de comportamento social, entre as quais se destacam três: primeiro, uma atitude geral em relação ao Estado de Direito. As contendas entre grupos rivais não se resolvem mediante apelo a códigos universais ou a tribunais de justiça pública. $\mathrm{O}$ único código reconhecido é a omertà (virilidade), cujo princípio fundamental interdita a prestação de informações a autoridades públicas. Esse tipo de comportamento social desenvolve-se em "sociedades que não gozam de ordem pública efetiva ou em sociedades cujos cidadãos encaram, hostilmente, parte ou a totalidade das autoridades (como, por exemplo, nas cadeias públicas ou no submundo fora delas) ou com menosprezo em relação a coisas realmente importantes (por exemplo, escolas) ou combinando ambas as coisas" (Hobsbawm, 1970, p. 49). Em segundo lugar, diz respeito ao patronato como forma de organização dominante. Onde quer que tenham se instalado, as máfias tiveram por eixo um chefe, todo poderoso, em torno do qual gravitava todo um corpo de dependentes e colaboradores, constituindo fina e complexa "rede de influência" capaz de oferecer e vender proteção. Na Sicília, o estabelecimento do patronato inviabilizou qualquer outra forma alternativa de poder contínuo. Terceiro, refere-se ao controle virtual e total da vida em uma comunidade qualquer por um secreto sistema de gangs. Neste particular, ressalta Hobsbawm, as máfias eram senão uma rede de gangs locais, controlando territórios determinados, via de regra uma comuna ou um latifundium, relacionadas entre si tão somente por intermédio das migrações de trabalhadores para colheitas, através das ligações entre proprietários, seus advogados e as cidades, bem como por meio das inúmeras feiras disseminadas pelo país. Suas características essenciais: violência desmedida, virilidade profissional, parasitismo e banimento, tudo controlado por rituais de iniciação e senhas meticulosamente padronizadas.

Como sugere o estudo de Hobsbawm, o nascimento, expansão e declínio das organizações mafiosas acompanharam pari passu as vicissitudes da vida econômica e política italiana. No início, meados do século XIX, as 
ADORNO, Sérgio. Conflitualidade e violência: reflexões sobre a anomia na contemporaneidade. Tempo Social; Rev. Sociol. USP, S. Paulo, 10(1): 19-47, maio de 1998.

${ }^{13}$ Haveria muito mais a dizer a respeito das organizações mafiosas. Por exemplo: quanto ao caráter organizado ou não de suas atividades, vejase Catanzaro (1991 e 1993). Além do mais, muita coisa foi escrita sobre a máfia nos Estados Unidos, em particular entre os anos 1910 e 1920 , em cidades como Nova York e Chicago. Um estudo interessantíssimo é o de H.M. Enzensberger (1967). Preocupado também em refletir sobre a construção de mitos em torno do gangsterismo, esse autor faz um belo estudo sobre a ascensão e queda de Al Capone. A par do mito que às suas voltas se constituiu, Capone procurou racionalizar os diversos empreendimentos criminais a que se dedicou seguindo à risca o modelo de empreendimento mercantil capitalista. Ademais, desde cedo, percebeu que a expansão de suas atividades dependia da condescência dos poderes políticos locais constituídos, razão do desenvolvimento de um complexo e sofisticado sistema de subornos e de venda de proteção que atraiu não apenas prefeitos, vereadores, magistrados, mas também de- máfias não assumiram de pronto sua faceta de organização de gangs. Floresceram no curso dos acontecimentos que convergiram para a unificação italiana. Para os grandes e pequenos proprietários de terra, sequiosos por se defenderem contra o explorador estrangeiro (o governo Bourbon ou o governo piemontês), as embrionárias máfias, de bases genuinamente populares, representavam um mecanismo de proteção social e de afirmação nacional local. Conforme anota Hobsbawm, essas primeiras organizações estiveram presentes nos movimentos revolucionários liberais de Palermo, de 1820, 1848 e 1860, assim como participaram do primeiro grande levante contra a dominação do capitalismo do Norte, em 1866.

Entre 1860 e 1890, as máfias transitaram para uma forma de organização política paralela ao poder de Estado. Combinando patronato políticosocial, regulado por rituais de referência e reafirmação do poder arbitrário do mais forte com formas modernas de representação política, as organizações mafiosas traduziram, em determinado momento da história social e política italianas, uma alternativa de participação no modelo de poder concêntrico instituído pelos potentados do Norte, modelo alimentado pelo liberalismo político em voga àquela época, último quartel do século passado. De fato, o surgimento de relações capitalistas no interior da sociedade italiana promoveu a politização dos operários fabris e dos camponeses que, com suas práticas políticas, vieram progressivamente substituir as velhas táticas de ódio incontido e conspirador presentes nos massacres que caracterizavam os levantes locais. Com a emergência dos novos atores sociais e políticos, a vocação revolucionária das máfias, seu espectro de movimento social de massas, declina acentuadamente, permanecendo restritos às áreas mais pobres e atrasadas da parte oriental da Sicília.

Ao mesmo tempo, uma das virtudes da política liberal veio alimentar o poder das máfias. Com o poder do Norte, alimentado pelo desenvolvimento das manufaturas que converteu o Sul em espécie de colônia agrária, veio também a modernidade política, ou seja, a extensão do direito de voto. Para os poderosos do Norte interessava contar com o apoio e mesmo a subserviência política do Sul, mesmo que para tanto fosse necessário subornar governos ou fazer concessões aos chefes locais. Se, do ponto de vista financeiro, concessões e subornos pouco representavam para o rico Norte, para o Sul representavam uma diferença ímpar, até há pouco inteiramente desconhecida: a possibilidade dos chefes locais penetrarem no universo dos interesses político-partidiários. Os chefes mafiosos converteram-se em chefes políticos locais.

Na verdade, tudo sugere o quanto os processos de acumulação de riqueza e de acumulação e concentração de poder tangiversaram as possibilidades de existência das organizações mafiosas, determinando-lhes inclusive sua deriva para o mundo da delinquiência, seja na própria Itália, seja nos Estados Unidos. Vale notar, contudo, que as organizações mafiosas jamais se colocaram como uma necessidade intrínseca da própria economia ou mesmo do desenvolvimento político. Nessa medida, não se constituíram em peça essen- 
ADORNO, Sérgio. Conflitualidade e violência: reflexões sobre a anomia na contemporaneidade. Tempo Social; Rev. Sociol. USP, S. Paulo, 10(1): 19-47, maio de 1998.

cial do poder político ou elemento indispensável ao funcionamento legal do aparelho de Estado. Disto resulta também que não lograram expansão para além de suas bases locais, às quais permaneceram via de regra aprisionadas. De fato, quando os lucros possíveis e o poder disponível estimularam as tensões entre as velhas e novas gerações de mafiosos, a alternativa foi emigrar e não a descoberta de outros territórios que pudessem servir de ampliação das redes e de acomodação dos interesses ${ }^{13}$.

Ao que tudo parece indicar, na contemporaneidade o crime organizado reaparece, agregando novas práticas às tradicionais ainda que guardem certa distância do modelo de organização das máfias italianas. O tráfico internacional de drogas, uma das modalidades atuais mais significativas de crime organizado, padece de problema semelhante. O narcotráfico compreende um conjunto diversificado de atividades e operações, o qual articula, em nível internacional, a produção (com todo o seu processo artesanal, semi-artesanal e industrial), a circulação, a distribuição e o consumo. Por intercambiar uma mercadoria proibida na maior parte das sociedades, o narcotráfico mobiliza toda uma "economia subterrânea": distintos mecanismos de acumulação (que compreendem uma combinação de formas de assalariamento, semiassalariamento, pagamento em espécie) geram uma renda da qual parte substantiva é apropriada na remuneração de atividades de suporte ou subsidiárias, como o abastecimento de armas, a manutenção de milícias locais particulares, o treinamento e formação de pistoleiros profissionais e, em especial, a manutenção de uma rede de colaboradores destinada a facilitar o transporte da droga, pelos mais variados meios, através das fronteiras entre países. Daí a necessidade de consumir vultuosos capitais para garantir postos privilegiados de circulação, entre os quais campos particulares de pouso. Daí também a funcionalidade da corrupção em toda essa "economia subterrânea", sediada inclusive em aeroportos, portos e zonas aduaneiras e alfandegárias (cf. Labrousse, 1994; Salama, 1994; Kozel \& Lambert, 1992; Arrieta et alii, 1991; Schiray, 1989,1992 e 1994; Fonseca, 1992) $)^{14}$.

Além do mais, essa modalidade de "economia subterrânea" é altamente verticalizada e verticalizadora. Ela tende a colonizar outras modalidades delituosas, submetendo-as a seu domínio. Atividades anteriormente realizadas por soturnos e individualizados delinquientes ou por bandos isolados, como roubos, seqüestros, contrabandos acabam articuladas ao narcotráfico. O caso do contrabando de armas é exemplar. Ele presta-se não somente a modernizar e nutrir o arsenal bélico sofisticado à disposição dos traficantes, como também a proporcionar fonte de renda adicional. A propósito, convém relembrar que a circulação monetária é fundamental nessa economia subterrânea, daí porque a "lavagem" de dinheiro, através de operações financeiras complexas e sofisticadas, porém dotadas de alguma segurança, é tão vital para a sobrevivência do narcotráfico. Daí também o papel estratégico desempenhado pelas instituições bancárias cuja cumplicidade é raramente colocada sob suspeição (cf. Arlacchi, 1992; Lewis, 1992). putados federais e senadores. Por fim, compreendeu a necessidade de conquistar o apoio dos poderosos sindicatos de trabalhadores. Seu declínio se dá justamente quando essa complexa rede de interesses mercantis e conluios políticos começa a ruir em parte na avalanche da profunda crise econômica da década de 1920.

${ }^{14} \mathrm{~A}$ bibliografia indicada reúne análises variadas sobre produção, distribuição, circulação e consumo de drogas, em especial cocaína, ópio, heroína, canabis, em distintos países. Com base em documentação disponível, os estudos apresentam avaliações quantitativas, examinam a diversidade de produtos, as relações entre procura e oferta, a geração de renda, a formação de preços, a concentração dos lucros, os mecanismos de retribuição aos distintos agentes que comparecem ao circuito produção/circulação/consumo, as conexões entre economia "subterrânea" e economia oficial, bem como o estratégico papel representado pela corrupção em seus mais distintos níveis. Sobre este último aspecto, ver Garcia Mendez (1989). 
ADORNO, Sérgio. Conflitualidade e violência: reflexões sobre a anomia na contemporaneidade. Tempo Social; Rev. Sociol. USP, S. Paulo, 10(1): 19-47, maio de 1998.

${ }^{15}$ Nas sociedades contemporâneas, os padrões de sociabilidade exacerbam o individualismo, conduzindo os homens a uma relação narcisística consigo mesmo. Os homens vêem o mundo como espelho de si mesmo e não se interessam por eventos externos a não ser que desenvolvam um reflexo de sua própria imagem. Impera uma cultura terapêutica, que cultua o corpo esteticamente disciplinado (cf. Lash, 1983 e 1986; Costa, 1986 e 1989; Guattari \& Rolnik, 1986). As relações entre público e privado alteram-se significativamente. $\mathrm{O}$ mundo da privação irrompeu a esfera pública, diluindo-a na luta pela necessidade. Ao fazer isso, introduziu na esfera pública elementos pré-políticos de regulamentação das atividades humanas e, sobretudo, da ação política. Possibilitou o isolamento e o desenraizamento dos homens, tornando-os estranhos à sua casa e ao seu mundo. Lançou a violência no cenário público, retraindo a capacidade humana de entendimento mútuo através do diálogo e da palavra (cf. Arendt, 1987; Habermas, 1981).

${ }^{16}$ Tudo indica que, onde quer que o tráfico internacional de drogas
Não bastassem essas conexões que o narcotráfico estabelece com o mercado e o Estado, ele também encadeia e introduz microscópicos desarranjos no tecido social. No passado, a organização delinqüente tinha claro as diferenças entre o mundo da ordem e da legalidade e o mundo dos ilegalismos. Havia nítida distinção entre trabalho e delinquiência. O narcotráfico rompeu com essa tradicional distinção. Muitos dos jovens recrutados em massa para a organização o são na condição de trabalhadores assalariados, não importando o posto que venham inicialmente a ocupar. Tal não significa contudo a introjeção de uma ética vocacional do trabalho ou a criação de uma solidariedade ombro a ombro. Ao contrário, institui-se uma competitividade tal, movida por um individualismo exacerbado e por uma desconfiança extremada em qualquer $u^{15}{ }^{15}$. Radicalizada até às últimas consequiências, essa competitividade é instituinte da guerra entre quadrilhas. Por isso, esses jovens, desde cedo socializados para o ingresso na guerra, o são também para lidar com a morte e sua iminência. Aqui se revela um dos mais agudos paradoxos da contemporaneidade: no ápice do processo civilizatório, os avanços tecnológicos estão colocando em evidência a fragilidade da vida, os inúmeros perigos e riscos que a cercam. Sob essa ótica, talvez o crime organizado constitua de fato o cerne do problema contemporâneo, menos pelos seus efeitos sobre a ordem e a legalidade e muito mais pelas incertezas que ele institui (cf. Pecaut, 1991 e 1994; Arrieta et alii, 1991) ${ }^{16}$.

De qualquer modo, o crime organizado também propõe problemas novos, insolúveis a curto prazo, para a Justiça penal. O que tem sido evidenciado, seja no narcotráfico, seja nos casos de alta corrupção envolvendo agentes do Estado, é que as leis penais não podem ser aplicadas do mesmo modo que são aplicadas às modalidades delituosas cometidas pelo delinqüente comum. Os processos penais que tem como alvo o crime organizado, em especial o tráfico internacional de drogas, ensejam uma complexidade ímpar. Em primeiro lugar, porque a natureza das operações é pouca conhecida. Envolve uma rede de atores, situados em múltiplos pontos da estrutura social com funções extremamente diferenciadas. Ademais, tudo funciona à base do segredo, "lei do silêncio" cuja transgressão é severamente punida, não raro com a morte de um suspeito, o que arrasta atrás de si toda uma cadeia de tantos outros suposta ou efetivamente comprometidos com a ruptura do pacto. Com isso dilui-se a materialidade da infração - a qual somente pode ser objeto de intervenção judicial caso perfeitamente caracterizada sob o ponto de vista das exigências legais -, bem como se dilui a precisa identificação da responsabilidade penal. Há ainda uma terceira situação. Diz respeito à aquela em que tanto a infração está perfeitamente caracterizada face aos requisitos legais, quanto são conhecidos seus prováveis autores. Contudo, a trama é de tal forma intrincada que não se pode estabelecer uma relação de causalidade, um nexo entre a materialidade da infração e seus possíveis autores. Assim, a justiça penal, fortemente influenciada pelos princípios liberais, cujo eixo principal repousa na suposição do livre arbítrio e, por conseguinte, na responsabili- 
ADORNO, Sérgio. Conflitualidade e violência: reflexões sobre a anomia na contemporaneidade. Tempo Social; Rev. Sociol. USP, S. Paulo, 10(1): 19-47, maio de 1998.

dade individual, fica impossibilitada de exercer uma de suas funções primordiais, qual seja a de assegurar a pacificação da sociedade mediante julgamento e responsabilização dos atos considerados lesivos à ordem pública.

Com isso, no âmbito também do narcotráfico, a materialidade do delito e a responsabilidade individual não são passíveis de perfeita e exata caracterização. Não sem motivos, quando a justiça penal consegue exercer alguma intervenção nessa área, seus resultados são irrisórios e seus efeitos pouco eficazes. Por que? Na maior parte das vezes em que situações como esta ocorrem, os acusados ou são consumidores, ou pequenos e médios traficantes que não desfrutam de um sistema privado de proteção e de imunidades contra a ação da Justiça. Essas intervenções, contudo, não resultam na desmontagem de toda uma organização que se recompõe em outros lugares e com novos recursos, e movida por outros indivíduos, recrutados para desempenharem as distintas funções de transporte, vigilância, venda etc. Essa parece ser uma situação típica, mesmo quando toda uma rede ou quadrilha tenha "caído" nas mãos da justiça penal. Exemplos de situações como essa são encontrados cotidianamente na crônica policial de cidades como Rio de Janeiro e São Paulo ${ }^{17}$. Para o cidadão comum, incapaz de compreender toda essa complexa rede de relações sociais que subordina a corrupção e o tráfico de influências ao narcotráfico, o que de fato releva é uma justiça penal "frouxa", inoperante, ineficiente, impossibilitada de ver reconhecida sua autoridade, conivente até por omissão com o crescimento da criminalidade urbana violenta. Não há razões, portanto, para se estranharem as opiniões favoráveis ao justiçamento privado e a outras modalidades privadas de punição e vingança, que compreendem, em sociedades como a brasileira, a aplicação de castigos físicos e mesmo da pena de morte, isto é, medidas que desprezam a mediação da Justiça pública.

Em conclusão, a partir de uma análise crítica de ensaio de Ralph Dahrendorf sobre a erosão da lei e da ordem na sociedade contemporânea, procurei desconstruir os argumentos contidos no ensaio sugerindo as mudanças que incidem sobre o modo de assujeitamento dos indivíduos. Mais do que liberação dos indivíduos dos liames e controles sociais, para além de um problema de "ligaduras", o que parece estar no centro das radicais transformações da ordem neste final do século é o modo como os indivíduos governam a si e aos outros (cf. Foucault, 1984). Para sustentar esta hipótese, tomei como "paradigma de análise" um caso: a colonização da criminalidade pelo crime organizado, em particular por ação de uma de suas modalidades mais emblemáticas de produção da violência no mundo contemporâneo - o narcotráfico. Esse recorte analítico e empírico conduziu-me a indagar: em que medida o pluralismo jurídico, cujos contornos começam a ser detectados, bem como as formas emergentes de contratualidade, não necessariamente enfeixadas no Estado, não estariam - ao promoverem mudanças no diagrama liberal (cf. Ewald, 1986) -, incidindo sobre tradicionais e convencionais concepções de se instale, ele institui uma guerra mortal entre quadrilhas e entre quadrilhas e forças da ordem. Seu sinal mais visível é o abrupto crescimento dos homicídios dolosos, em especial envolvendo jovens do sexo masculino. Recente estudo, conduzido pelo pesquisador colombiano Luis Ratinoff, revelou que a média desses homicídios, na Colômbia oscila entre 77,0 e 77,9 ocorrências/cem mil habitantes. O mesmo estudo indicou que a média brasileira oscila entre 24,0 e 24,9 ocorrências/cem mil habitantes (cf. Folha de S. Paulo, 18/03/96, caderno 1, p. 9). Trata-se de médias elevadas se considerarmos que, nos Estados Unidos, ela é da ordem de 10 ocorrências/cem mil habitantes. Evidentemente, essas médias são muito mais elevadas em cidades como Medellin, Rio de Janeiro ou São Paulo. Convém observar também que as mortes voluntárias são igualmente elevadas na Itália, por força do crime organizado, agora em escala internacional, mantido pelas máfias. Ver Savona (1993) e Pezzino (1991).

${ }^{17}$ De certo modo, podese estabelecer uma analogia entre os efeitos do narcotráfico sobre o Estado, em par- 
ADORNO, Sérgio. Conflitualidade e violência: reflexões sobre a anomia na contemporaneidade. Tempo Social; Rev. Sociol. USP, S. Paulo, 10(1): 19-47, maio de 1998.

ticular sobre a justiça penal, e os efeitos do crime organizado pelas máfias sobre o Estado italiano, recentemente deslindados pela Operação "Mãos Limpas". Uma análise interessante encontra-se em Meldolesi (1994), que sugere o quanto arraigados estavam os hábitos políticos italianos em sua conivência com o crime organizado e com a corrupção. "Dessa forma, hoje sabemos aquilo que no fundo sempre deveríamos ter sabido. Ou seja, que o sistema dos partidos do governo por muito tempo financiou-se impondo um tributo medieval a muitas transações econômicas que requerem o beneplácito das autoridades públicas; que esse sistema se aperfeiçoou com o tempo, à medida em que a concorrência entre concorrentes e partidos internos e externos à esfera governamental fazia fermentar o custo da política; e que com isso se instituíra uma propina cujo percentual variava de transação para transação, propina essa que por sua vez era repartida percentualmente entre as diversas facções, de acordo com sua influência (nacional ou local); que essa "lei" se impôs amplamente à responsabilidade penal centrada no indivíduo, pouco compatíveis com a emergência e generalização do crime organizado?

Bem, penso que essa breve e impressionista descrição do crime organizado sugere que os problemas sociais contemporâneos são muito mais complexos do que aventou Dahrendorf. As formas explosivas de litigiosidade, nos mais diferentes campos da existência social, não se acomodam às fórmulas e parâmetros ditados pela "institucionalização" ou "democratização" dos conflitos na sociedade industrial. Como Dahrendorf, concordamos que o crime e suas formas de punição representam um dos mais candentes problemas contemporâneos. Discordamos contudo quanto à natureza desse problema. Segundo me parece, o problema não reside na erosão da lei e da ordem, que é senão um efeito, porém na inadequação dos controles sociais tradicionais e convencionais à "sociedade de risco" (Ewald, 1986), modo como se pode qualificar as sociedades contemporâneas. Por isso, é preciso repensar o estatuto do controle social na contemporaneidade.

O controle social, algo mais amplo do que o controle da ordem pública, parece ter esgotado suas funções no interior de modelos tradicionais. Por um lado, os mecanismos de pressão social sobre o comportamento dos indivíduos, que operaram sobretudo na esfera da moralidade, pública e privada, não parecem suscitar nem o sentimento de medo, sequer o de angústia diante das possibilidades, sempre abertas, de violação das normas sociais. É como se operasse uma sorte de dissociação entre as imposições morais e as práticas sociais. Segundo Roché, "nossas sociedades urbanas e complexas liberaram o homem do controle social. Elas abriram oportunidades em todos os domínios, e notadamente em matéria de delinquiência" (Roché, 1994, p. 13).

Por um lado, nunca é demais lembrar, em A Educação Moral (1963), Durkheim defende a tese de que somente a submissão à regra exterior, impessoal e abstrata é capaz de conter as "forças rebeldes" que habitam o indivíduo, contendo portando os apetites imoderados e o individualismo exacerbado. Essa luta de si para consigo traduz-se em educação moral cujos princípios fundantes são: disciplina, adesão a um grupo social e autonomia da vontade. Preenchidos esses requisitos, a sociedade pode funcionar em sua regularidade. Ora, a moralidade na sociedade contemporânea parece justamente caminhar em sentido oposto. Em lugar da aposta no universalismo, na austeridade eno autocontrole, a moral contemporânea é hedonista e particularista, valoriza a espontaneidade, a dessublimação da vida pulsional, a inversão da relação paixão-razão, impulso e prazer como afirmadores da existência (cf. Sennett, 1987; Lash 1983 e 1986). Nesse movimento, não é estranho que questões éticas tenham e venham sendo trazidas para o centro do debate contemporâneo. De igual modo, não é fora de propósito que a corrupção, uma prática tão antiga quanto rotineira em nossas sociedades, tenha se constituído em problema social e político senão recentemente (cf. Martins, 1994). No interior desse cenário, parece pouco razoável fiar-se a obediência às normas na existência suposta de um sujeito autônomo, por natureza cioso das virtudes da disciplina social. 
Por outro lado, as éticas vocacionais, muitas delas dotadas de forte inspiração religiosa, que, no passado, asseguravam o represamento das pulsões e do desejo (cf. Weber, 1974), se não mais parecem mecanismos sólidos para conter os conflitos dos indivíduos entre si e com a sociedade, muito menos ainda o são para evitar as tensões entre coletivos sociais. Está-se em plena era das paixões, sem que quaisquer interditos ou freios morais subjetivos consigam objetivar a experiência social. Os homens vêem o mundo como espelho de si mesmo e não se interessam por eventos externos a não ser que desenvolvam um reflexo de sua própria imagem. Deixaram de compartilhar um fundo comum de signos públicos. Assim, torna-se impossível a busca do auto-interesse esclarecido (Sennett, 1987; Rouanet, 1987). O sinal mais visível desse processo reside na acentuada perda de eficácia da ética vocacional do trabalho, cujos efeitos se manifestam em todas as classes sociais, em particular entre as classes trabalhadoras.

O esgotamento dos modelos convencionais de controle social sugere, por conseguinte, que é preciso repensá-lo. E repensá-lo a partir do lugar onde ele foi originalmente concebido pela teoria sociológica clássica, qual seja, a sociedade. A complexa problemática do controle social não se encerra no domínio exclusivo dos aparelhos repressivos de Estado. Com isso, penso que a crítica e "problematização" das "demandas contemporâneas por ordem social" sofrem um deslocamento em seu eixo de referência: do poder político para o poder social. Tal perspectiva compreende a reflexão sobre as formas de interação e sociabilidade em emergência, quer entre as classes populares, quer entre as demais classes sociais, bem como as modalidades de socialização que informam o comportamento sobretudo dos jovens na sociedade contemporânea e que fomentam variadas interpretações acerca do uso das normas e de sua eficácia, prática e simbólica. Nesse terreno, impõe-se investigar os modelos de autoridade em emergência, repertoriando os múltiplos e atuais sentidos atribuídos a todos os elementos que compõem o universo normativo, como as leis, os direitos, as instituições, as sanções, bem como o peso que figuras de autoridade - como o pai, o patrão, o conselheiro local, o delegado, o magistrado, o padre, a parteira, o grupo de pares etc. - ocupam resignificadas nos processos de socialização em curso. Tal perspectiva vem, nesse sentido, recuperar um dos objetos mais tradicionais da teoria sociológica clássica, cujas questões pareciam, até há pouco, completamente elucidadas, qual seja, o processo de socialização.

Por fim, uma agenda que se proponha repensar o estatuto do controle social, problematizando suas formulações tradicionais e convencionais, não pode ignorar o papel do Estado no controle social, em particular no controle da ordem pública. Todavia, esse papel não pode mais ser examinado em termos de eficácia ou fracasso. Dahrendorf afirma, nos ensaios citados, que um dos problemas fundamentais da sociedade contemporânea é que o controle da ordem pública na sociedade moderna foi inspirado em Locke e Rousseau, porém, ao implementá-lo, essa mesma sociedade se encontrou face a face, e indústria, às finanças e a diversos setores da economia italiana que mantiveram relações de negócio com o sistema político (a penalidade para infração dessa "lei" era a exclusão das empreitadas, encomendas, autorizações etc); que tal sistema se tornou moeda-corrente a ponto de envolver (provavelmente) a maioria dos políticos. [...] Sabemos ainda que a corrupção política alimentou a corrupção administrativa. [...] Sabemos também que os partidos de oposição tem participado mais esporadicamente do banquete" (Meldolesi, 1994, p. 8). A longa citação traduz a extrema imbricação entre diferentes atores e instituições, constituindo uma rede densa e complexa. A apuração da responsabilidade penal dos promotores e participantes desta rede encontrou inúmeros obstáculos, dadas as dificuldades de caracterização efetiva dos delitos e de seus prováveis autores, conforme o próprio Meldolesi sugere. 
${ }^{18}$ Sob essa ótica, um programa de investigação que se proponha repensar o controle social na contemporaneidade vai ter de enfrentar algumas espinhosas questões, mais propriamente afetas à filosofia do direito, como as mutações substativas que vem ocorrendo em, pelo menos, alguns "paradigmas" (perdoem-me o emprego nem um pouco adequado do conceito) que estruturam o campo e o saber jurídico, em particular as noções de responsabilidade, culpabilidade, contrato, reciprocidade, equiidade. mesmo se identifica, com o Estado leviatã de Hobbes. Com isso, creio, o sociólogo liberal está fazendo menção ao fato de que o controle social (inclusive o controle da criminalidade) se espreme entre duas forças antagônicas: por um lado, a anarquia social que seria decorrente de propostas irrealistas de justiça social; por outro lado, o autoritarismo, inspirador de propostas que supõem desprezo, suspensão ou violação de direitos individuais. Ora, impõese neste capítulo justamente colocar a questão fora desses termos dicotômicos. É preciso problematizar a própria natureza, perfil e funções do Estado na contemporaneidade, as quais extravasaram os limites ditados pelo modelo contratual de organização societária. Como vêm demonstrando vários analistas, em particular Boaventura de Sousa Santos (1995), cabe considerar que, na atualidade, o Estado é cada vez mais caracterizado pelo pluralismo jurídico e pela coexistência de mais de uma ordem jurídica no mesmo espaço geopolítico, o que contrasta com as clássicas funções e características do Estado moderno. Nesse terreno, é preciso lembrar que vivemos sob a égide de uma "civilização do risco" que arrasta atrás de si importantes consequiências políticas, em especial para as formas de controle social penal, tudo enfeixado em torno de um Estado de Prevenção. Trata-se de uma modalidade de organização estatal, voltada prioritariamente para a prevenção e para a segurança, tendente a orientar-se segundo normas e mecanismos decisórios que reorganizam sem cessar reações a situações de urgência estrutural ou conjuntural (Wagner \& Baratta, 1994). Trata-se, por conseguinte, de um Estado armado contra o perigo e que tende a ver inimigos por toda a trama do tecido social ${ }^{18}$.

Para terminar, talvez se esteja agora em condições de lançar uma hipótese explicativa para uma questão anteriormente formulada: pode ser que a obsessão punitiva de nossa sociedade contemporânea, materializada nas chamadas "demandas por ordem social", explique-se justamente pelo modo de funcionamento da sociedade de risco que edifica toda uma imensa e resistente superestrutura de prevenção e segurança (através da proliferação das sociedades de seguro e dos mecanismos de vigilância privada) para fazer face aos medos, perigos e ameaças que tornam a vida humana, social e intersubjetiva, absolutamente incerta. Daí porque, no bojo de fenômenos aparentemente tão diferentes e distanciados no tempo e no espaço, como sejam as catástrofes, as epidemias, os acidentes, o desemprego crônico, extremismos políticos, os crimes esteja um mesmo e único problema: uma profunda crise de racionalidade que atravessa a sociedade contemporânea de alto a baixo e que coloca sob suspeição todas as apostas nas virtudes do progresso técnico, da modernização e do bem-estar proporcionado pela sociedade industrial. 
ADORNO, Sérgio. Conflict and violence: reflections on anomy in the contemporary world. Tempo Social; Rev. Sociol. USP, S. Paulo, 10(1): 19-47, may 1998.

ABSTRACT: Based on a critical analysis of the essay Law and Order (1985) by Ralf Dahrendorf about the erosion of law and order in contemporary society, this article reviews the arguments of the essay pointing out the changes involved in the modes of subjection of the individuals. What is in question in the present turn-of-the-century context of radical transformations is rather the way individuals govern themselves and each other (Foucault, 1984) than the liberation of each individual from social ties and controls - the problem of "ligatures". In order to justify this hypothesis, the analytical reference is a specific case: the colonization of urban criminality by organized crime, specially by one of the most emblematic examples of violence production in contemporary world: drug-trafficking.

\section{REFERÊNCIASBIBLIOGRÁFICAS}

Adorno, S. (1996) A gestão urbana do medo e da insegurança. São Paulo, 281 p. Tese (Livre-Docência). Faculdade de Filosofia, Letras e Ciências Humanas da Universidade de São Paulo.

ARendt, H. (1987) A condição humana. Rio de Janeiro, Forense-Universitária.

Arieta, C.G. \& Orjuela, L.J. \& Palacio, E.S. \& Tokatlian, J.G. (1991) Narcotrafico en Colombia. Dimensiones políticas, económicas, jurídicas e internacionales. Bogotá, Universidad de los Andes/ Ediciones Uniandes/Tercer Mundo Editores.

ARlaCchi, P. (1992) De la mafia au marché libre: drogue et criminalité dans la province de Vérone. In: Ehrenberg, A. \& Mignon, P. (orgs.). Drogues, politique et société. Paris, Éditions Descartes.

Bercovich, A. \& Dellasoppa, E. \& Arriaga, E. (1997) Violence, civil rights and democracy in Brazil: the case of the metropolitan area of Rio de Janeiro. Paper presented at Annual Meeting of the Population Association of America, session 7. The Demography of Violence: Evidence from the Americas. March 27-29, 1997. Washington, DC.

CAtAnZaro, R. (1991) Cosche - Cosa Nostra: la structure organisationnelle de la criminalité mafieuse en Sicile. Cultures \& Conflits (Mafia, Drogue et Politique), Paris, Centre d'Études des Conflits L'Harmattan, 3: 9-23, automne.

(1993) La régulation sociale par la violence: le rôle de la criminalité organisée dans l'Italie Méridionale. In: BRAUD, P. (ed.). La violence politique dans les démocraties européennes occidentales. Paris, L'Harmattan, p. 173-186.

CoHEN, B. (1974) Reporting crime: the limits of statistical and field data. In: BluMBERG, A. (ed.). Current perspectives on criminal behaviour.

UNITERIMS:

anomy, authority, law and order, violence, organized crime, drug-trafficking. 
New York, Alfred Knopf.

CostA, J.F. (1986) Sobre a "geração AI-5": violência e narcismo. In: Violência e psicanálise. Rio de Janeiro, Graal, p. 117-188.

. (1989) Narcisismo em tempos sombrios. In: FERNANDEs, Heloísa Rodrigues (org.). Tempo do desejo. Sociologia e psicanálise. São Paulo, Brasiliense, p. 109-136.

Cusson, M. (1990) De l'évolution pénale. Déviance et Société, Gèneve, 14(3): 315-323.

Dahrendorf, R. (1981) Sociedade e liberdade. Coleção Pensamento Político, 16. Brasília, UnB.

. (1982) As classes e seus conflitos na sociedade industrial. Coleção Pensamento Político, 28. Brasília, UnB.

. (1985) Law and Order. London, Stevens \& Sons.

. (1987) A lei e a ordem. Brasília, Instituto Tancredo Neves.

- (1992) O conflito social moderno. Um ensaio sobre a política da liberdade. São Paulo/Rio de Janeiro, Edusp/Jorge Zahar Editor.

Durkheim, E. (1963) De la division du travail social. Paris, Presses Universitaires de France.

. (1965) L'education morale. Paris, Presses Universitaires de France.

Enzensberger, H. M. (1967) Politique et crime. Paris, Gallimard.

ERBÈs, J.M. (1990-1991) La gestion privée de la sécurité. Différentes conceptions de l'exercice de la police. Les Cahiers de la Sécurité Intérieure, Paris, IHESI/La Documentation Française, 3: 61-80, novembre-janvier.

Ewald, F. (1986) L'État providence. Paris, Payot.

FERnANDEs, H. (1994) Sintoma social dominante e moralização infantil. São Paulo, Edusp/Escuta.

FONSECA, G. (1992) Économie de la drogue: taille, caractéristiques et impact économique. Revue Tiers Monde, XXXIII(131): 489-516, juilletseptembre.

Foucault, M. (1966) Les mots et les choses. Paris, Gallimard.

. (1977) Vigiar e punir. História da violência nas prisões. Petrópolis, Vozes.

. (1979) Microfísica do poder. Rio de Janeiro, Graal.

. (1984) História da sexualidade II. O uso dos prazeres. Rio de Janeiro, Graal.

Garcia Mendez, E. (1989) Les approches de la corrupcion: le centre et la péripherie. Déviance et Société, Gèneve, 13(3): 223-229. 
GidDEns, A. (1984) Sociologia: uma breve, porém crítica introdução. Rio de Janeiro, Zahar.

Gove, W. R. \& Hughes, M. \& GeERKen, M. (1985) Are uniform crimes reports a valid indicator of the index crimes? An affirmative answer with minor qualifications. Criminology, Bervely Hills, 23(3): 451-501, aug.

Guattari, F. \& Rolnik, S. (1986) Cartografias do desejo. Petrópolis, Vozes.

Habermas, J. (1987). Théorie de l'agir communicationnel. Vol.1. Paris, Fayard.

HoBsBawm, E.J. (1970) Rebeldes primitivos. Estudo sobre as formas arcaicas dos movimentos sociais nos séculos XIX e XX. Rio de Janeiro, Zahar.

Hulsman, L. (1990) Réponse à Maurice Cusson. Déviance et Société, Gèneve, 14(3): 325-334.

Izzo, A. (1991) Storia del pensiero sociologico. Bologna, Il Mulino.

Kozel, N \& LAMBert, E.Y. (1994) L'abus de drogue aux États-Unis. Une évaluation à partir de données épidémiologiques et ethnographiques. Futuribles, Paris, 185: 57-72, mars.

Labrousse, A. (1994) Géopolitique de la drogue. Les contradictions de "guerre à la drogue". Futuribles, Paris, 185: 9-22, mars.

Lagrange, H. \& Roché, S. (1993) L'insécurité: histoire et regulation. Études et Recherches, Paris, IHESI/Institut des Hautes Études de la Sécurité Intérieure (mimeo).

LAHALlE, A. et alii (1994) Jeunes délinquants et jeunes en danger en milieu ouvert. Toulouse, Érès.

LASH, C. (1983) A cultura do narcisismo. A vida americana numa era de esperanças em declínio. Rio de Janeiro, Imago.

(1986) O mínimo eu. Sobrevivência psíquica em tempos difíceis. São Paulo, Brasiliense.

LEWIS, R. (1992) La distribution et la consommation de drogues entre l'Écosse et l'Italie du Sud. In: Ehrenberg, A. \& Mignon, P. (orgs.). Drogues, politique et société. Paris, Descartes.

ManNHEIM, Karl. (1953) Essays on sociology and social psycology. London, Routledge Kegan Paul.

. (1980) O pensamento conservador. In: Martins, J. S. (org.). Introdução crítica à sociologia rural. São Paulo, Hucitec.

Marshall, T.B. (1967) Cidadania, classe social e status. Rio de Janeiro, Zahar.

MARTINS, J. S. (1994) O poder do atraso: ensaios de sociologia da história lenta. São Paulo, Hucitec. 
Meldolesi, L. (1994) Problemas de reforma do Estado: crime, corrupção, trapaça, parasitismo, incúria. Sucessos, limites, lições do caso italiano. Revista Brasileira de Ciências Sociais, São Paulo, ANPOCS, 24: 5-15, fevereiro.

MiLIBAND, Ralph. (1969) The state in capitalist society. London, Weindenfeld \& Nicolson.

Nozick, Robert (1974) Anarchy, state and utopia. New York, Basic Books.

O’Donnell, G. (1988) Transições, continuidades e alguns paradoxos. In: REIS, F.W. \& O'Donnell, G. A democracia no Brasil. Dilemas e perspectivas. São Paulo, Vértice, p.41-71.

Ocqueteau, F. \& Pottier, M.L. (1995) La vigilance dans les grandes surfaces. Paris, L'Harmattan/IHESI.

OCQUETEAU, F. (1988) Une réglementation française sur le secteur de la sécurité privée. Pourquoi? Déviance et Société, Genève, 12(4): 383-389.

. (1990-1991) Les marchés de la sécurité privée: développement et implications. Différentes conceptions de l'exercice de la police. Les Cahiers de la Sécurité Intérieure, Paris, IHESI/La Documentation Française, 3: 81-111, novembre-janvier.

Pecaut, D. (1991) Trafic de drogue et violence en Colombie. Cultures \& Conflits (Mafia, Drogue et Politique), Paris, Centre d'Études des Conflits/L'Harmattan, 3: 141-156, automne.

. (1994) Violence et politique: quatre élements de réflexion a propos de la Colombie. Cultures \& Conflits (Disparitions), Paris, Centre d'Études des Conflits/L'Harmattan, 13-14: 155-166.

Pezzino, P. (1991) La modernisation violente en Italie. Perspective historique du crime organisé. Déviance et Société, Génève, 15(4): 419-437.

PInHeIro, P. S. (1991) Autoritarismo e transição. Revista USP, São Paulo, 9: 45-56, março-maio.

RaWLS, John (1971) A theory of justice. Havard University Press.

Robert, Ph. \& VAn Outrive, L. (1993) Crime et justice en Europe. État des recherches, évaluations et recommandations. Paris, L'Harmattan.

Robert, Ph. \& Zauberman, R. (1995) Du côté des victimes: un outre regard sur la délinquance. Paris, L'Harmattan.

Robert, Ph. \& Aubusson de Cavarlay, B. \& Pottier, M.L. \& Tournier, P. (1994) Les comptes du crime. Les délinquences en France et leurs mesures. Paris, L'Harmattan.

Roché, S. (1994) Insécurité et libertés. Collection L'épreuve des faits. Paris, Seuil.

Rouanet (1987) As razões do iluminismo. São Paulo, Companhia das Letras. 
Salama, P. (1994) Macro-économie de la drogue dans les pays andins. Futuribles, Paris, 185: 43-56, mars.

SAvona, E. U. (1993) La dynamique du crime organisé en Italie. Cahiers de la Sécurité Intérieure, Paris, IHESI/La Documentation Française, 14: 167-178, août-octobre.

Schiray, M. (1989) Essai sur l'illégalité en économie: l'économie de la drogue. Sciences Sociales et Santé, VII(3): 5-25. (1992) La Grand-Bretagne. Approches nationales des marchés européens. In: Schiray, M. (org.). Penser la drogue, penser les drogues. II-Les marchés interdits de la drogue. Paris, Descartes. (1994) Les filières-stupéfiants: trois niveaux, cinq logiques. Futuribles, Paris, 185: 23-41, mars.

Sennett, R. (1987) O declínio do homem público. As tiranias da intimidade. São Paulo, Companhia das Letras.

Sousa Santos, B. (1995) Pela mão de Alice. O social e o político na pósmodernidade. São Paulo, Cortez.

WACQÜANT, L. (1996) De l'État charitable à l'Etat pénal - notes sur le traitement politique de la misère en Amérique. Regards Sociologiques, 11: 30-38, mai.

Wagner, H. \& BaratTA, A. (1994) Débat: société du risque et contrôle social. Risque, sécurité et démocratie. Déviance et Société. Gèneve, 18(3): 331-2.

Weber, M. (1974) Economía y sociedad. 4ª reimpressão. México, Fóndo de Cultura Económica.

Weiner, N.A. \& WolfGang, M. (1985) The extend and character of violent crime in America. In: CURTIS, L.A. American violence and public police. Un update of the National Comission on the causes and prevention of violence. New Harven and London, Yale University Press, p. 15-39.

Wright, K.N. (1987) The great american crime myth. New York, Praeger. 